\title{
La ley sobre derechos civiles de la mujer: una igualdad efectiva
}

Beatriz Ramos Cabanellas

ORCID: 0000-0003-2708-4489

Universidad Católica del Uruguay

Correo: bramos@ucu.edu.uy

El día 11 de setiembre de 1946, la Asamblea General aprobó la ley n. ${ }^{\circ} 10.783$ denominada Ley de Derechos Civiles de la Mujer, siendo promulgada el día 18 de los mismos mes y año. Previamente a su aprobación, estaba vigente el régimen del Código Civil que, si bien había resultado inobjetable para su época, ya no era satisfactorio al realizar la mujer, en forma cada vez más habitual, tareas remuneradas fuera del hogar. Es por ello que se presentaron algunos proyectos de ley con el objetivo de reformarlo. ${ }^{1}$

El proyecto de ley que finalmente resultó aprobado no fue ninguno de los presentados en forma previa, ya que el mismo surgió en la Comisión del Senado, siendo, en parte, el resultado de la amalgama de parte de algunos de ellos. Esta ley, de apenas 22 artículos, dio pasos importantes en el camino a la igualdad entre el hombre y la mujer, en la medida en que la misma reconoció igual capacidad civil a ambos, dando un golpe de gracia tanto a la potestad marital como a la potestad parental.

A la potestad marital, en la medida en que por esta ley se modificó en forma sustancial las normas de funcionamiento (administración y persecución de acreedores) del régimen de bienes matrimonial. Hasta su vigencia, el marido era el único administrador de los bienes maritales, dotales y de los gananciales. Es decir, que durante el régimen conyugal el marido administraba todos los bienes, incluso los propios de la mujer. La ley n. ${ }^{\circ} 10.783$ dispuso en su artículo $2^{\circ}$ que la mujer casada tuviera la libre administración de sus bienes propios, así como la de los gananciales adquiridos por ella.

A su vez, dispuso la necesidad de la conformidad de ambos cónyuges para la enajenación o afectación con derechos reales de bienes inmuebles adquiridos por cualquiera de ellos, así como para la enajenación de una casa de comercio, un establecimiento agrícola o ganadero o una explotación industrial o fabril de carácter ganancial. De igual manera, dispuso que la fijación del domicilio conyugal se hiciera de

\footnotetext{
${ }^{1}$ Vaz Ferreira en su Tratado de la Sociedad Conyugal refiere como proyectos presentados en forma previa a dicha ley el Proyecto de Brum presentado al Poder Legislativo en el año 1923; Proyecto de Código de los derechos civiles de la mujer, presentado en el año 1930; Proyecto de Etchegoyen, presentado en 1938; Proyecto de Frugoni, publicado en 1940 y proyecto de Alvarez Vignoli de Demichelli, presentado en 1946. 
común acuerdo entre los cónyuges, así como que ambos contribuyeran a los gastos del hogar en forma proporcional a su situación económica.

A la potestad parental, pues en su artículo 11 se dispuso que la patria potestad fuera ejercida en forma conjunta por ambos cónyuges. Previamente, dicho poder era ejercido en forma exclusiva por el padre, con la lógica incidencia en la crianza de los hijos. Desde luego que estas disposiciones incidieron en forma directa en la familia uruguaya, ya que al equilibrar el poder entre los cónyuges perfiló un rol más independiente de la mujer y del poder de decisión de la misma respecto a la educación y formación de los hijos.

En dicha ley también se regularon otros temas de importancia, como el derecho de persecución de los acreedores durante la vigencia de la sociedad conyugal, así como una nueva regulación de la separación judicial de bienes como causal de disolución de la sociedad conyugal.

La ley empleó un método de derogación tácita, que, como bien resalta Vaz Ferreira, fue un acierto, aunque trajo dudas de interpretación. Finalmente, sus disposiciones, al igual que las de otras leyes, fueron incorporadas en la actualización del Código Civil aprobado por la ley n. ${ }^{\circ} 16603$ de octubre de 1994.

La denominación de esta ley no puede pasar inadvertida, ya que refiere a los "derechos civiles de la mujer" y demuestra la importancia de las denominadas leyes civiles. La Constitución de la República del año 1934 en su artículo 8 reconoció la igualdad de las personas ante la ley, no reconociendo otra distinción que los talentos y las virtudes. ${ }^{2}$ Sin embargo, fue recién en el año 1946, por la Ley de Derechos Civiles de la Mujer que se dispuso la igual capacidad civil de la mujer y el hombre.

De esta forma, la ley objeto de este prólogo estuvo en línea con el pensamiento del argentino Alberdi cuando decía: "las leyes civiles no son sino leyes orgánicas de las disposiciones de la Constitución Nacional". ${ }^{3}$

Transcurridos 75 años de su promulgación, diversas disposiciones de esta ley continúan plenamente vigentes, habiendo sido un hito fundamental en el camino del reconocimiento de los derechos de la mujer, así como en la relación entre padres e hijos.

\section{Prof. Beatriz Ramos Cabanellas}

\footnotetext{
${ }^{2}$ Artículo 8 ley n. ${ }^{\circ}$ 10783: “Todas las personas son iguales ante la Ley, no reconociéndose otra distinción entre ellas sino la de los talentos o las virtudes", es decir se reconocía la igualdad de las personas.

${ }^{3}$ Alberdi, J. J. (1887). Obras completas (tomo VI). Buenos Aires: La Tribuna. p. 105.
} 